\title{
PEMANTAUAN PENDERITA DIABETES MELLITUS
}

\author{
F. Y. Widodo \\ Bagian Biokimia Fakultas Kedokteran Universitas Wijaya Kusuma Surabaya \\ Email : fywidodo@gmail.com
}

\begin{abstract}
Abstrak
Diabetes mellitus adalah penyakit yang ditandai dengan adanya hiperglikemia, yang disebabkan oleh karena gangguan sekresi insulin, gangguan kerja insulin, atau keduanya. Hiperglikemia yang kronis akan mengakibatkan disfungsi dan kerusakan berbagai organ, misalnya pada mata, ginjal, syaraf, jantung, dan pembuluh darah.

Tulisan ini membahas tentang pemantauan penderita diabetes mellitus berdasakan pemeriksaan laboratorium, untuk mengetahui kapan hasil terapi telah mencapai titik optimum serta upaya pencegahan terhadap komplikasi-komplikasi yang dapat terjadi.
\end{abstract}

Kata Kunci : Diabetes mellitus, pemeriksaan laboratorium, komplikasi

\section{MONITORING OF PATIENT WITH DIABETES MELLITUS}

\begin{abstract}
Diabetes mellitus is a disease characterized by hyperglycemia, which is caused by impaired insulin secretion, impaired insulin action, or both. Chronic hyperglycemia will lead to dysfunction and damage to various organs, such as the eyes, kidneys, nerves, heart, and blood vessels.

This paper discusses the monitoring of patients with diabetes mellitus according to the laboratory tests, to know when the results of therapy has reached the optimum point as well as the prevention of complications that can occur.
\end{abstract}

Keywords : Diabetes mellitus, laboratory tests, complications

\section{PENDAHULUAN}

Diabetes Melitus merupakan suatu kelompok penyakit metabolik dengan karakteristik hiperglikemia karena kelainan sekresi insulin, kerja insulin atau keduaduanya. Etiologi penyakit ini dapat berasal dari kombinasi faktor genetik dan faktor pengaruh lingkungan ${ }^{1,2}$.

Pada tahun 2000, diperkirakan sekitar 150 juta orang di dunia mengidap diabetes mellitus. Jumlah ini diperkirakan 
akan meningkat menjadi dua kali lipat pada tahun 2005, dan sebagian besar peningkatan itu akan terjadi di negara yang sedang berkembang seperti Indonesia. Populasi penderita diabetes di Indonesia diperkirakan berkisar antara 1,5 sampai 2,5\% kecuali di Manado sebesar 6\%. Dengan jumlah penduduk sekitar 200 juta jiwa, berarti lebih kurang 3-5 juta penduduk Indonesia menderita diabetes ${ }^{3}$.

Hingga tahun 2012, diseluruh dunia penderita diabetes mellitus mencapai 371 juta jiwa. Populasi penderita diabetes mellitus di Indonesia pada tahun yang sama mencapai 7,6 juta jiwa. Ini merupakan urutan ke 7 terbanyak dari jumlah penderita diabetes mellitus di seluruh dunia, dan yang terdeteksi hanya sekitar 3 juta jiwa atau hanya sekitar 39\% saja. Dari jumlah itu yang meninggal dunia akibat diabetes mellitus di Indonesia mencapai lebih dari 150.000 jiwa per tahun, dan lebih dari separuhnya meninggal dibawah usia 60 tahun ${ }^{4}$. Kebanyakan pasien tersebut meninggal akibat komplikasi dari penyakit diabetes mellitus. Komplikasi ini timbul tergantung dari lamanya penyakit ini diderita atau dari keparahan penyakit itu sendiri. Komplikasi yang dimaksud disini adalah komplikasi makrovaskuler dan mikrovaskuler.
Komplikasi makrovaskuler dapat menyebabkan timbulnya penyakit jantung koroner, penyakit pembuluh darah otak, dan penyakit pembuluh darah perifer. Komplikasi mikrovaskuler terjadi akibat hiperglikemia yang persisten dan pembentukan protein yang terglikasi (termasuk $\mathrm{HbA} 1 \mathrm{c}$ ), yang mendorong timbulnya retinopati, nefropati dan neuropati 1,2 .

Tujuan dari tulisan ini bukan untuk menjelaskan secara rinci tentang patofisiologi dan terapi diabetes yang sudah banyak dibicarakan, namun untuk mengetahui cara pencegahan timbulnya komplikasi hingga menimbulkan kematian, yaitu dengan cara mengetahui target sampai seberapa penurunan kadar gula darah penderita yang harus dicapai, serta melakukan pemeriksaan penunjang yang lain, dengan tujuan mewaspadai timbulnya komplikasi.

\section{GLUKOSA DARAH}

Kadar glukosa darah pada keadaan pos-absorbsi berkisar antara 4,5 - 5,5 mmol/l (80 - $100 \mathrm{mg} / \mathrm{dl})$. Setelah makan makanan yang mengandung tinggi karbohidrat, akan naik menjadi 6,5 - 7,2 mmol/l (120 - 130 mg/dl). Saat puasa, kadar 
glukosa darah turun hingga 3,3 - 3,9 mmol/l $(60-70 \mathrm{mg} / \mathrm{dl})$. Penurunan kadar yang mendadak dapat menyebabkan kejangkejang, akibat ketergantungan otak akan pasokan glukosa ${ }^{5}$.

\section{A. Sumber Glukosa Darah}

Sebagian besar karbohidrat yang berasal dari makanan akan membentuk glukosa, galaktosa atau fruktosa, yang kemudian akan diangkut ke hati lewat vena porta. Galaktosa dan fruktosa akan dikonversi menjadi glukosa. Glukosa dapat diperoleh dari senyawa-senyawa glukogenik (misalnya asam amino, asam laktat dan gliserol) yang mengalami glukoneogenesis. Sumber glukosa darah yang lain bisa berasal dari proses glikogenolisis di hati ${ }^{5}$.

\section{B. Pengendalian Enzimatis}

Sel hati memiliki permeabilitas terhadap glukosa yang lebih tinggi daripada sel-sel lain. Impermeabilitas sel ekstrahepatik disebabkan oleh membran sel yang menghalangi masuknya glukosa kedalam sel. Glukosa yang telah masuk, akan segera mengalami fosforilasi oleh enzim heksokinase. Kecepatan pengambilan glukosa dalam hati maupun jaringan ekstrahepatik tergantung pada kadar glukosa darah.
Apabila konsentrasi glukosa darah meningkat, maka glukosa akan dibawa ke hati melalui vena porta. Pada kadar glukosa yang normal, hati merupakan satu-satunya penghasil glukosa. Tetapi, bila kadar glukosa meningkat, pengeluaran glukosa dari hati akan terhenti ${ }^{5}$.

\section{Pengendalian oleh Hormon}

Hormon pengendali kadar glukosa darah yang utama adalah insulin. Insulin akan menyebabkan pengambilan glukosa oleh otot dan jaringan lemak. Hal ini karena adanya peningkatan transport glukosa melalui membran sel. Insulin disekresi kedalam sirkulasi darah sebagai respon langsung keadaan hiperglikemia. Asam amino, asam lemak bebas, keton, glukagon, sekretin dan tolbutamida, dapat merangsang pengeluaran insulin ${ }^{5}$.

Hormon-hormon lain seperti glukagon, GH, ACTH, glukokortikoid, hormon tiroid, dan epinefrin, bertindak sebagai hormon-hormon diabetogenik, yang masing-masing memiliki kekhususan bekerja dengan mekanisme yang berbedabeda untuk mempengaruhi pelepasan insulin, serta menyebabkan glikogenolisis dalam hati dan otot dengan cara merangsang fosforilase ${ }^{5}$. 


\section{Pengendalian oleh Ginjal}

Secara terus menerus, glukosa akan difiltrasi oleh glomeruli. Karena adanya sistem reabsorbsi dari tubulus ginjal, maka glukosa akan kembali masuk kedalam sirkulasi darah. kapasitas sistem tubuler untuk mereabsorbsi glukosa memiliki batas ambang. Bila kadar glukosa meningkat, sebagian glukosa akan terbuang melalui urine. Glukosuria akan terjadi apabila kadar glukosa darah vena melebihi 10,0 mmol/1, atau setara dengan $180 \mathrm{mg} / \mathrm{dl}^{5}$.

\section{E. Toleransi Glukosa}

Menurunnya toleransi glukosa adalah sebagai akibat menurunnya sekresi insulin. Manifestasi dari hal tersebut, berupa naiknya kadar glukosa darah (hiperglikemia) dan glukosuria. Toleransi glukosa juga bisa menurun karena adanya obesitas. Penurunan toleransi glukosa juga bisa terjadi pada kerusakan hepar, beberapa penyakit infeksi, obat-obatan, hiperaktifitas kelenjar hipofisa dan korteks adreanal yang menghasilkan hormon-hormon antagonis insulin ${ }^{5}$.

Pemberian suntikan insulin akan menurunkan kadar glukosa darah, dimana penggunaan serta penyimpanan glukosa sebagai glikogen dalam otot dan hati akan ditingkatkan. Kelebihan dosis insulin dapat menyebabkan hipoglikemia, yang akan menyebabkan kejang-kejang, dan bahkan kematian. Peningkatan toleransi glukosa juga nampak pada insufisiensi kelenjar hipofisa atau korteks adrenal, dimana akan terjadi penurunan kadar hormon-hormon yang bekerja secara antagonis dengan insulin 5 .

\section{DIABETES MELLITUS}

Penyakit diabetes mellitus atau yang dikenal dengan sebutan kencing manis adalah suatu penyakit gangguan metabolisme kronis yang ditandai dengan peningkatan kadar gula disertai dengan gangguan metabolisme karbohidrat, lipid dan protein, sebagai akibat oleh defisiensi produksi insulin oleh pankreas, atau sel-sel tubuh kurang responsif terhadap insulin, atau bisa kedua-duanya ${ }^{1,2}$.

\section{Klasifikasi}

Klasifikasi diabetes mellitus berdasarkan etiologinya adalah sebagai berikut $^{6,1,2}$ :

1. Diabetes Mellitus Tipe 1 : defisiensi insulin absolut akibat destruksi sel beta

2. Diabetes Mellitus Tipe 2 : bervariasi mulai dari resistensi insulin predominan disertai defisiensi insulin relatif, sampai 
defek sekresi insulin predominan disertai resistensi insulin

3. Diabetes Tipe Lain : akibat defek genetik fungsi sel beta, defek genetik kerja insulin, penyakit eksokrin pankreas, endokrinopati, obat/bahan kimia, infeksi, imunologi, dan sindroma genetik lain.

4. Diabetes Gestasional : pada kehamilan

5. Pra-diabates : IFG (Impaired Fasting Glucose) dan IGT (Impaired Glucose Tolerance)

\section{DIAGNOSIS}

Dari anamnesis sering didapatkan keluhan khas diabetes berupa poliuria, polidipsi, polifagia dan penurunan berat badan yang tidak jelas penyebabnya., Keluhan lain yang sering disampaikan adalah lemah badan, kesemutan, gatal, mata kabur, disfungsi ereksi dan pruritus vulvae 1,2 .

Diagnosis ditegakkan dengan pemeriksaan kadar gula darah sebagai berikut ${ }^{6,1,2}$ :

1. Gula darah puasa $\geq 126 \mathrm{mg} / \mathrm{dl}$; atau

2. Gula darah $2 \mathrm{jam} \geq 200 \mathrm{mg} / \mathrm{dl}$; atau

3. Gula darah acak $\geq 200 \mathrm{mg} / \mathrm{dl}$.

Acuan ini berlaku diseluruh dunia, dan di Indonesia Departemen Kesehatan RI juga menyarankan untuk mengacu pada ketentuan diatas ${ }^{3}$. Cara diagnosis yang lain adalah dengan mengukur HbAlc $\geq 6,5 \%{ }^{6}$.

Pra-diabetes adalah penderita dengan kadar glukosa darah puasa antara $100 \mathrm{mg} / \mathrm{dl}$ sampai dengan $125 \mathrm{mg} / \mathrm{dl}(I F G)$; atau 2 jam puasa antara $140 \mathrm{mg} / \mathrm{dl}$ sampai dengan 199 $\mathrm{mg} / \mathrm{dl}(I G T)$, atau kadar A1C antara 5,7$6,4 \%{ }^{6,7}$.

\section{KOMPLIKASI}

\section{Hipoglikemia}

Serangan hipoglikemia ditandai dengan perasaan pusing, lemas, gemetar, mata berkunang-kunang, keringat dingin, detak jantung meningkat, sampai hilang kesadaran. Hipoglikemnia biasanya timbul bila kadar glukosa darah $\leq 50$ $\mathrm{mg} / \mathrm{dl}$, dan ini terjadi apabila dosis obat anti diabetes atau insulin terlalu tinggi, makan terlalu sedikit, olahraga terlalu berat, minum alkohol atau depresi ${ }^{8,1,2}$.

\section{Hiperglikemia}

Hiperglikemia yang dimaksud disini adalah suatu keadaan dimana kadar gula darah tiba-tiba melonjak. Hal ini disebabkan antara lain oleh stress, infeksi, dan konsumsi obat-obatan tertentu. Hiperglikemia ditandai dengan poliuria, 
polidipsia, polifagia, kelelahan yang parah, dan pandangan kabur. Hipergikemia dapat memperburuk gangguan-gangguan kesehatan seperti gastroparesis, disfungsi ereksi, dan infeksi jamur pada vagina. Hiperglikemia yang berlangsung lama dapat berkembang menjadi keadaan metabolisme yang berbahaya antara lain ketoasidosis diabetik (Diabetic Ketoacidosis), yang dapat berakibat fatal dan membawa kematian. Hiperglikemia dapat dicegah dengan kontrol kadar gula darah yang ketat ${ }^{1,2}$.

\section{Komplikasi Makrovaskuler}

Komplikasi makrovaskular yang umum berkembang pada penderita diabetes adalah penyakit jantung koroner, penyakit pembuluh darah otak, dan penyakit pembuluh darah perifer ${ }^{1,2}$. Komplikasi makrovaskular lebih sering timbul pada DM tipe 2, yang umumnya menderita hipertensi, dislipidemia dan atau kegemukan, walaupun komplikasi makrovaskular dapat juga terjadi pada DM tipe 1. Kombinasi dari penyakitpenyakit tersebut dikenal dengan sebutan Sindroma Metabolik 9,10. Penyakit jantung sangat besar risikonya pada penderita diabetes, maka pencegahan komplikasi terhadap jantung sangat penting dilakukan, termasuk pengendalian tekanan darah, kadar kolesterol dan lipid darah. Penderita diabetes sebaiknya selalu menjaga tekanan darahnya tidak lebih dari 130/80 $\mathrm{mm} \mathrm{Hg}{ }^{11}$. Penderita harus dengan sadar mengatur gaya hidupnya, termasuk mengupayakan berat badan ideal, diet dengan gizi seimbang, berolah raga secara teratur, tidak merokok, dan mengurangi stress ${ }^{12}$.

\section{Komplikasi Mikrovaskuler}

Komplikasi ini terutama terjadi pada penderita diabetes tipe 1. Komplikasi mikrovaskuler yang timbul antara lain retinopati, nefropati, dan neuropati. Disamping karena kondisi hiperglikemia, ketiga komplikasi ini juga dipengaruhi oleh faktor genetik. Untuk berkembang kearah komplikasi mikrovaskular, tergantung lamanya (durasi) sakit dan tingkat keparahan diabetes. Satu-satunya cara untuk mencegah atau memperlambat jalan perkembangan komplikasi mikrovaskular adalah dengan pengendalian kadar gula darah yang ketat. Pengendalian yang paling intensif 
ialah dengan menggunakan suntikan insulin ${ }^{13,1}$.

\section{Penatalaksanaan}

Penatalaksanaan diabetes bertujuan untuk menurunkan morbiditas dan mortalitas, yang secara spesifik ditujukan untuk mencapai 2 target utama, yaitu menjaga agar kadar glukosa plasma berada dalam kisaran normal, dan mencegah kemungkinan terjadinya komplikasi ${ }^{13,3}$.

Ada dua pendekatan dalam penatalaksanaan diabetes, pertama adalah pendekatan tanpa obat dan yang kedua adalah pendekatan dengan obat. Penatalaksanaan tanpa obat berupa edukasi, terapi gizi dan latihan jasmani. Apabila dengan langkah pertama ini tujuan penatalaksanaan belum tercapai, dapat dikombinasikan dengan langkah farmakologis berupa terapi obat hipoglikemik oral, terapi insulin, atau kombinasi keduanya ${ }^{13,14}$. Obat hipoglikemik yang dipakai pada intervensi farmakologis adalah ${ }^{14,8,15}$ :

1. Sulfonilurea: Glibenkalmid, Glipizid, Gliklazid, Glimepirid, dll.

2. Meglitinid: Repaglinid, Nateglinid

3. Biguanid: Metformin
4. Penghambat glukosidase: Acarbose, Miglitol

5. Tiazolidindion: Rosiglifazon, Pioglitazon

6. Incretin / DPP-4 inhibitor: Sitagliptin, Saxogliptin, Vildagliptin.

7. Injeksi GLP-1 reseptor agonis: Exenatide, Liraglutide.

Obat yang sering kali dipakai sebagai awal terapi adalah Metformin ${ }^{8}$. Namun, apabila kadar glukosa darah belum mencapai target terapi, diperlukan kombinasi dengan obat jenis lain ${ }^{16,17}$.

Indikasi pemakaian insulin sebagai terapi adalah $^{14,2}$ :

1. Diabetes mellitus tipe 1

2. Diabetes mellitus tipe 2, apabila terapi obat hipoglikemik oral saja tidak bisa memenuhi target terapi.

3. Keadaan stres berat, seperti pada infeksi berat, tindakan pembedahan, infark miokard akut atau stroke

4. Penderita diabetes yang hamil apabila diet saja tidak dapat mengendalikan kadar glukosa darah.

5. Gangguan fungsi ginjal atau hati yang berat

6. Kontra indikasi atau alergi terhadap obat hipogligemik oral 
7. Ketoasidosis diabetik, Hiperglikemia hiperosmolar non ketotik, Hiperglikemia dengan asidosis laktat

\section{KONTROL GLIKEMIK DAN PENCEGAHAN KOMPLIKASI TERHADAP}

Setelah pasien didiagnosis dengan diabetes, disarankan pasien tersebut memeriksakan diri ke dokter paling tidak sebulan sekali. Pada saat kontrol, dipantau tentang cara minum obat, diet dan latihan jasmani. Yang lebih penting, pasien disarankan untuk melakukan monitor kadar glukosa darah secara mandiri (selfmonitoring of blood glucose $=S M B G)$. Hal ini akan sangat membantu pasien untuk bisa mengetahui kadar gula darahnya setiap waktu, sehingga pasien mengetahui naikturunnya kadar gula darah, termasuk mengetahui apabila timbul komplikasi hipoglikemik secara dini. Frekuensi SMBG tergantung dari masing-masing individu, tergantung tipe diabetes, tipe terapi, kontrol glikemik yang adekuat, kewaspadaan terhadap keadaan hipoglikemik, kesibukan pekerjaan pasien, dan penyakit akut ${ }^{13,18}$.

Disarankan untuk pasien diabetes baik tipe 1 maupun tipe 2 yang menggunakan terapi MDI (multi-dose insulin) atau pompa insulin, harus memeriksa kadar gula darah 3 kali atau lebih dalam sehari, yaitu setiap selesai makan (makanan utama dan kudapan), mau tidur, saat latihan fisik, serta saat hendak melakukan kegiatan tertentu seperti misalnya mengemudikan kendaraan. Sedangkan untuk penderita diabetes tipe 2 , baik yang menggunakan obat maupun yang tidak, tergantung dari kebutuhan masingmasing individu. Telah terbukti bahwa kontrol glukosa darah lebih baik pada penderita yang mengaplikasikan SMBG daripada yang tidak. ${ }^{13,18}$.

Untuk memantau timbulnya komplikasi, perlu ditanyakan adanya gangguan penglihatan, keadaan kaki, adanya infeksi, timbul rasa nyeri, kesemutan atau penurunan sensasi raba, serta disfungsi seksual pada pria. Pada pemeriksaan fisik perlu diperiksa vital sign, termasuk nadi, tekanan darah, suhu, dan respiratory rate. Perlu juga diperiksa ketajaman penglihatan, detak jantung, keadaan kulit, keadaan kaki, pemeriksaan saraf, dan berat badan ${ }^{13}$.

\section{Pemantauan Kadar Gula Darah}

Target glikemik harus tergantung pada keadaan individu penderita, berdasarkan usia, lama sakit diabetes, resiko hipoglikemia berat, adanya pernyakit 
kardiovaskuler, serta life expectancy. Target yang diharapkan ialah, untuk glukosa darah puasa antara $72-125 \mathrm{mg} / \mathrm{dl}$, dan 2 jam setelah makan antara $90-180 \mathrm{mg} / \mathrm{dL}^{13,7}$.

Selain pemeriksaan kadar glukosa darah, para ahli juga menyarankan untuk melakukan pemeriksaan kadar HbAlc / A1C. Targetnya adalah $\leq 7,0 \%$, dimana faktor resiko mikrovaskuler dan makrovaskuler dapat ditekan. Lebih jauh, untuk menurunkan resiko nefropati dan retinopati pada penderita diabetes tipe 2 , A1C disarankan $\leq 6,5 \%$. Untuk penderita diabetes tipe 2 dengan keadaan yang sudah parah, serta terdapat komplikasi-komplikasi antara lain penyakit arteri koroner, pernah hipoglikemia berat dan keadaan berat yang lain, target A1C adalah 7,1\% - 8,5\% 6,7,19.

Pemeriksaan kadar A1C ini bisa memperkirakan kadar glukosa darah selama 3 - 4 bulan. Perlu dilakukan pemeriksaan setiap 3 bulan sekali guna melihat efektifitas terapi ${ }^{18}$.

\section{Pemantauan Tekanan Darah}

Penyakit kardiovaskuler merupakan komplikasi yang sering timbul pada penderita diabetes, dan hipertensi seringkali dijumpai pula pada penderita diabetes, dan menjadi faktor resiko terjadinya komplikasi penyakit kardiovaskuler dan mikrovaskuler. Disarankan, tekanan darah harus selalu dikontrol secara lebih ketat pada penderita diabetes. Didalam populasi pada umumnya untuk penderita hipertensi, tekanan darah sistol harus dijaga selalu dibawah 140 $\mathrm{mmHg}$, atau dibawah $130 \mathrm{mmHg}$ pada pasien yang lebih muda (atau bisa dicapai tanpa pengobatan yang berat), dengan tekanan diastol dibawah $90 \mathrm{mmHg}$. Untuk penderita diabetes, tekanan sistol harus selalu dibawah $130 \mathrm{mmHg}$, dan diastol dibawah $80 \mathrm{mmHg}{ }^{6,11}$.

Apabila tekanan darah melebihi ketentuan, maka harus diterapi, baik secara non-farmakologis terlebih dahulu maupun terapi farmakologis. Penderita harus selalu menjaga berat badan ideal, makan makanan sehat, melakukan aktifitas fisik, dan tidak merokok. Jenis obat yang disarankan untuk dipakai adalah ACE inhibitor atau ARB (angiotensin receptor blocker), kadangkadang perlu terapi kombinasi dengan diuretik. Disini fungsi ginjal harus selalu dimonitor. Obat-obatan antiplatelet tidak selalu dipakai untuk pencegahan penyakit kardiovaskuler pada penderita diabetes, obat ini hanya dipakai pada penderita yang sudah menderita penyakit kardiovaskuler saja, 
karena ditakutkan malah bisa menimbulkan perdarahan gastrointestinal ${ }^{13,20}$.

\section{Pemantauan Profil Lipid}

Penderita diabetes (khususnya tipe 2) menunjukkan peningkatan prevalensi abnormalitas dari profil lipid, yang selanjutnya berperan pada resiko terjadinya penyakit kardiovaskuler, dimana resiko tersebut 2 sampai 4 kali lipat lebih besar apabila dibandingkan dengan yang tidak terkena diabetes. Sehingga, perlu suatu penatalaksanaan yang agresif terhadap faktor-faktor resiko penyakit kardiovaskuler, termasuk penatalaksanaan dislipidemia pada penderita diabetes ${ }^{13,21}$.

Yang paling sering terjadi pada penderita diabetes tipe 2 adalah hipertrigliseridemia, penurunan Kolesterol HDL, sedangkan kolesterol LDL biasanya normal atau sedikit meningkat. Disarankan, saat pasien didiagnosis diabetes, harus diperiksa pula profil lipid, dan diulang setiap tahun. Apabila ada kelainan dan diobati, untuk memantau hasil pengobatan, maka perlu dilakukan pemeriksaan setiap 3 sampai 6 bulan. Target yang diinginkan adalah kadar kolesterol LDL < $100 \mathrm{mg} / \mathrm{dL}$, kolesterol HDL > $40 \mathrm{mg} / \mathrm{dL}$ pada pria dan > $50 \mathrm{mg} / \mathrm{dL}$ pada wanita, dan trigliserida <
$150 \mathrm{mg} / \mathrm{dL}$. Apabila ada komplikasi penyakit kardiovaskuler, kadar kolesterol LDL harus $<70 \mathrm{mg} / \mathrm{dL}^{13,21}$.

Terapi non farmakologis yang disarankan adalah mengurangi makanan tinggi lemak jenuh dan kolesterol, meningkatkan konsumsi makanan berserat, mengandung lemak tak jenuh, pengurangan berat badan, dan latihan fisik. Obat yang disarankan disamping perubahan gaya hidup adalah statin, yang diberikan kepada yang telah terdiagnosis penyakit kardiovaskuler, atau tidak menderita penyakit kardiovaskuler namun berumur $>40$ tahun, dan memiliki faktor resiko kardiovaskuler. Penderita dengan kadar trigliserida > 10,0 mmol/l (180 mg/dl) perlu diterapi dengan golongan fibrat, untuk mengurangi resiko pankreatitis ${ }^{6,21}$.

\section{Pemantauan Nefropati Diabetes}

Pada penderita diabetes, harus dilakukan pemantauan terhadap penyakit ginjal kronis (Chronic Kidney Disease = CKD). Albumin urin dan Kreatinin serum perlu diperiksa. Berikutnya ditentukan besaran Ratio Albumin Kreatinin (Albumin to Creatinin Ratio $=\mathrm{ACR}$ ) serta hasil pemeriksaan kreatinin serum dikonversi 
menjadi eGFR untuk menentukan derajat penyakit ginjal kronik (apabila terjadi). Pada penderita diabetes tipe 2 , pemeriksaan harus segera dilakukan begitu diagnosis ditegakkan, sedangkan pada penderita diabetes tipe 1 dilakukan 5 tahun kemudian setelah diagnosis ditegakkan. Pemeriksaan kemudian diulang setiap tahun. ${ }^{13,22}$.

Diagnosis penyakit ginjal kronik (CKD) ditegakkan apabila ACR $\geq 2,0$ $\mathrm{mg} / \mathrm{mmol}$ (30 ug/mg kreatinin), atau eGFR < $60 \mathrm{ml} / \mathrm{min}$, yang dilakukan $2-3$ kali pemeriksaan dalam waktu 3 bulan. Pasien diabetes dengan CKD harus memperoleh berbagai cara penanganan yang komprehensif untuk mencegah resiko penyakit kardiovaskuler. Terapi yang dianjurkan untuk penderita diabetes dengan CKD dimana terdapat hipertensi atau albuminuria ialah diberikan ACE inhibitor atau ARB untuk menghambat progresifitas CKD, namun juga dianjurkan untuk selalu memantau kadar kreatinin serum dan kadar kalium dalam 1-2 minggu awal terapi dan saat serangan akut ${ }^{6,22}$.

\section{Pemantauan Retinopati}

Untuk mencegah retinopati, perlu dilakukan pemantauan kadar glukosa darah dan tekanan darah yang optimal. Pada penderta diabetes tipe 1 diatas umur 10 tahun, pemeriksaan mata harus dilakukan dalam waktu 5 tahun setelah diketahui penyakitnya. Sedangkan penderita diabetes tipe 2 harus diperiksa oleh dokter spesialis mata segera setelah diagnosis ditegakkan. Sebaiknya dilakukan pemeriksaan ulang setiap tahun, atau apabila pemeriksaan terdahulu tidak ditemukan kelainan retinopati, pemeriksaan bisa diulang setelah setiap 2-3 tahun. Pemeriksaan ulang dilakukan lebih singkat bila ditemukan kelainan ${ }^{13,23}$.

\section{Pemantauan Neuropati}

Salah satu faktor resiko timbulnya gangguan neuropati adalah peningkatan kadar gula darah. Selain itu, adanya peningkatan trigliserida, obesitas, merokok dan hipertensi juga merupakan faktor resiko penting. Kontrol kadar gula darah yang intensif merupakan cara yang efektif untuk mencegah neuropati pada diabetes tipe 1 . Pada penderita diabetes tipe 2, penurunan kadar gula darah berhubungan dengan penurunan frekuensi timbulnya neuropati. Pada penderita diabetes tipe 2, pemantauan neuropati perifer harus dimulai saat diagnosis ditegakkan, dan perlu diulang setiap tahun. Pada penderita diabetes tipe 1, 
pemeriksaan tiap tahun dilakukan setelah 5 tahun. Biasanya tidak diperlukan pemeriksaan yang canggih, hanya perlu pemeriksaan klinik sederhana saja, seperti misalnya tes persepsi monofilament dan vibrasi untuk neuropati. Sebaiknya pemeriksaan ini dilakukan oleh dokter Spesialis Saraf. Pemeriksaan ini selain dapat mengidentifikasi timbulnya neuropati, juga bisa meramalkan gangguan yang bakal terjadi dimasa yang akan datang ${ }^{13,24}$.

\section{Pemantauan Ulkus}

Komplikasi ulkus pada kaki menjadi masalah morbiditas yang besar pada para penderita diabetes, dapat menambah beban biaya pengobatan, bahkan beberapa penderita perlu dilakukan amputasi, serta meningkatkan mortilitas. Pengelolaan ulkus pada kaki memerlukan pendekatan interdispliner, yang antara lain harus dilakukan pemantauan kadar gula, pemantauan infeksi, pemantauan keadaan vaskularisasi tungkai bawah, dan perawatan luka. Terapi dengan menggunakan antibiotika tidak terlalu diperlukan pada ulkus neuropati yang tidak menunjukkan adanya tanda-tanda infeksi ${ }^{25}$.

Pemantauan harus dilakukan setiap tahun, dan lebih sering pada penderita resiko tinggi. Yang dilakukan adalah memeriksa keadaan dan temperatur kulit, abnormalitas struktural (misalnya ruang gerak sendi pergelangan kaki dan jari-jari, callus, deformitas tulang), neuropati, penyakit arteri perifer, luka dan infeksi. Penderita resiko tinggi perlu mendapatkan edukasi untuk selalu menghindari trauma, memakai alas kaki yang nyaman, dan segera berobat apabila terjadi luka di kaki. Hal ini perlu dilakukan guna mencegah terjadinya komplikasi lebih lanjut sampai harus dilakukan amputasi kaki. Prinsip umum penanganannya meliputi pemberian kompres basah, debridement jaringan yang rusak, serta mengurangi beban pada daerah yang mengalami tekanan ${ }^{13,25}$.

\section{Disfungsi Ereksi}

Angka kejadian disfungsi ereksi pada pria penderita diabetes adalah antara $34 \%$ sampai dengan 45\%. Hal ini telah menunjukkan efek yang buruk pada kualitas hidup penderita diantara semua usia, dan mungkin merupakan tanda awal dari penyakit kardiovaskuler. Untuk menghindari hal tersebut, semua pria dewasa yang menderita diabetes harus secara berkala dipantau fungsi seksualnya dan apakah terjadi hipogonadisme. Sebagai terapi lini 
awal (first-line therapy) biasanya diberikan Phosphodiesterase-5 inhibitor (PDE5 inhibitor), apabila tidak ditemukan adanya kontraindikasi. Pengawasan dan pengobatan harus dilakukan oleh dokter yang ahli dibidang ini ${ }^{13,26}$.

\section{Perlemakan Hati}

Peningkatan kadar transaminase hati, seringkali terkait dengan peningkatan insulin puasa, disamping peningkatan trigliserida, obesitas, dan penurunan kolesterol HDL. Pada wanita, peningkatan kadar transaminase terkait dengan diabetes tipe 2 dan hipertensi. Diabetes secara nyata juga terkait dengan terjadinya insiden penyakit liver kronis non-alkoholik (nonalcoholic chronic liver disease) ${ }^{6}$.

\section{KESIMPULAN}

Dari uraian diatas, dapat disimpulkan tujuan dari pengobatan (baik nonfarmakologis maupun farmakologis) dan peman-tauan terus menerus pada pendertia diabetes adalah:

1. Meningkatkan harapan hidup penderita dengan kualitas hidup yang optimal, sehingga penderita tetap produktif, serta dapat berfungsi dan berperan aktif dalam masyarakat.
2. Menekan komplikasi yang mungkin timbul.

3. Menekan biaya perawatan.

Pemantauan yang harus dilakukan terhadap penderita diabetes adalah:

1. Target untuk glukosa darah puasa antara $72-125 \mathrm{mg} / \mathrm{dl}$, dan 2 jam setelah makan antara $90-180 \mathrm{mg} / \mathrm{dl}$

2. Kadar HbA1c / A1C $\leq 6,5 \%$

3. Tekanan darah $<130 / 80 \mathrm{mmHg}$

4. Kadar kolesterol LDL $<100 \mathrm{mg} / \mathrm{dl}$, kolesterol HDL > $40 \mathrm{mg} / \mathrm{dl}$ pada pria dan > $50 \mathrm{mg} / \mathrm{dl}$ pada wanita, dan Trigliserida $<150 \mathrm{mg} / \mathrm{dl}$.

5. Albumin Kreatinin Ratio < $30 \mathrm{ug} / \mathrm{mg}$ kreatinin; eGFR > $60 \mathrm{ml} / \mathrm{min}$.

6. Transaminase hati harus dalam batas normal

7. Pemeriksaan mata dan neurologis berkala.

\section{DAFTAR PUSTAKA}

1. Masharani, U. Diabetes Mellitus and Hypoglicemia. on Current Medical Diagnosis \& Treatment. $15^{\text {th }}$ ed. The McGraw-Hill Companies, Inc. 2011. p. $1140-76$.

2. Powers, A. C. Diabetes Mellitus, on Harrison's Principles of Internal Medicine. Vol II, 17th ed. McGrawHill Medical, New York. 2008. p. $2275-2304$. 
3. Direktorat Bina Farmasi Komunitas dan Klinik. Pharmaceutical Care untuk Penyakit Diabetes Melitus, Departemen Kesehatan RI. 2005. on www.binfar.depkes.go. id.

4. IDF. IDF Diabetes Atlas; $5^{\text {th }}$ ed. International Diabetes Federation. 2012.

5. Bender, D.A. Gluconeogenesis \& the Control of Blood Glucose; on Harper's Illustrated Biochemistry; 28th ed. McGraw-Hill. 2009. p. 165 -173 .

6. ADA. Diagnosis and Classification of Diabetes Mellitus. Diabetes Care. 2013. 36, Supp 1 : S67 - 74

7. Imran, A.; et al; 2013; Targets for Glycemic Control; Can J Diabetes; vol. 37; supp. 1; p. S31 - S34.

8. Inzucchi, S. E., R.M. Bergenstal, J.B. Buse, M. Diamant, E. Ferrannini, M. Nauck, et al. Management of Hyperglycemia in Type 2 Diabetes: A Patient-Centered Approach. Diabetes Care. 2012. 35(6) : 13641379.

9. Ceska, R. Clinical Implications of Metabolic Syndrome: Diab. \& Vasc Dis Res. 207. Vol. 4; Supp 2.

10. IDF. The IDF Consensus Worldwide Definition of The Metabolic Syndrome. IDF Communication. 2006.

11. Arguedas. J.A., M.I. Perez, J.M. Wright. Blood Pressure Targets for Hypertension in People with Diabetes Mellitus. Cochrane Datab Syst Rev. 2013. No. 10.
12. Schulze, M.B. and F.B. Hu. Primary Prevention of Diabetes: What Can Be Done and How Much Can Be Prevented?. Annu Rev Public Health. 2005. 26 : 445-467.

13. ADA. Standards of Medical Care in Diabetes - 2013. Diabates Care. 2013. 36, Supp 1: S11 - 66

14. Eko, V. Terapi Diabetes Mellitus. CDK. 2011. edisi 182: $13-20$.

15. Kennedy, M.N. Pancreatic Hormones \& Antidiabetic Drugs. on Katzung Basic and Clinical Pharmacology. $12^{\text {th }}$ ed. The McGraw-Hill Med. 2011. p. 743768.

16. Bosi, D. F. Dotta, Y. Jia, M. Goodman. Vildagliptin plus metformin combination therapy provides superior glycaemic control to individual monotherapy in treatment-naive patients with type 2 diabetes mellitus. Diabetes Obes Metab. 2009. 11(5) : 506-515.

17. Ji, L.N., C.Y. Pan, J.M. Lu, H. Li, Q. Li, Q.F. Li, Y.D. Peng et al., Efficacy and safety of combination therapy with vildagliptin and metformin versus metformin uptitration in Chinese patients with type 2 diabetes mellitus: study design and rationale of the vision study. Cardiovascular Diabetology. 2013. 12 (118).

18. Berard, L.D., I. Blumer, R. Houlden, D. Miller, V. Woo. Monitoring Glycemic Control. Can J Diabetes. 2013. 37, Supp. 1: S35 - S39. 
19. Lu, Z.X., K.Z. Walker, K. O’Dea, K.A. Sikaris, J.E. Shaw. A1C for Screening and Diagnosis of Type 2 Diabetes in Routine Clinical Practice: Diabetes Care. 2010. 33(4) : 817-819.

20. Stone, J.A., D. Fitchett, S. Grover, R. Lewanczuk, P. Lin. Vascular Protection in People with Diabetes. Can J Diabetes. 2013. 37, supp. 1 : S100 - S104.

21. Mancini, G.B.J.; Dyslipidemia. Can J Diabetes. 2013. 37, supp. 1 : S110 $-\mathrm{S} 116$.

22. McFarlane, P., R.E. Gilbert, L. MacCallum, P. Senior. Chronic Kidney Disease in Diabetes. Can J Diabetes. 2013. 37, supp. 1 : S129 S136.

23. Boyd, S.R., A. Advani, F. Altomare, F. Stockl. Retinopathy. Can J Diabetes. 2013. 37, supp. 1 : S137 S141.
24. Bril, V.B., B. Perkins, C. Toth. Neuropathy. Can J Diabetes. 2013. 37, supp. 1 : S142 - S144.

25. Bowering, K. and J.M. Embil . Foot Care. Can J Diabetes. 2013. 37, supp. 1 : S145 - S149.

26. Brock, G. and W. Harper. Erectile Dysfunction. Can J Diabetes. 2013. 37, supp. 1 : S150 - S152. 